\title{
Bacillus cohnii sp. nov., a New, Obligately Alkaliphilic, Oval- Spore-Forming Bacillus Species with Ornithine and Aspartic Acid Instead of Diaminopimelic Acid in the Cell Wall
}

\author{
ROLAND SPANKA AND DAGMAR FRITZE* \\ DSM-Deutsche Sammlung von Mikroorganismen und Zellkulturen GmbH, \\ Mascheroder Weg 1b, D-3300 Braunschweig, Germany
}

\begin{abstract}
A group of 20 alkaliphilic Bacillus strains in which all strains revealed the same unique combination of properties-obligate alkaliphily, oval spores distending the sporangium, and ornithine and aspartic acid instead of diaminopimelic acid in the cell wall-was examined. Most of the strains had been isolated by a five-step enrichment and isolation procedure. The $G+C$ content was determined to span a range from 33.5 to 35.0 mol\%. Unsaturated fatty acids amounted to 17 to $28 \%$ of the total cellular fatty acids. Through DNA-DNA hybridization experiments 11 strains could be grouped in one species. Low homology values with the type strains of validly published Bacillus species with similar $\mathbf{G}+\mathbf{C}$ contents suggest that these strains belong to a hitherto undescribed species for which the name Bacillus cohnii is proposed. The type strain of the new species is strain RSH (= DSM 6307).
\end{abstract}

More than 100 years ago, in 1872, Ferdinand Cohn described the genus Bacillus (8). Sixty-two years later Vedder isolated and described the first alkaliphilic Bacillus species: Bacillus alcalophilus (35). Although a considerable number of alkaliphilic Bacillus strains have been isolated in the past years, $B$. alcalophilus has been until now, the only validly published obligately alkaliphilic Bacillus species.

Gordon and Hyde were the first, in 1982, to present a comprehensive work on the taxonomy of alkaliphilic Bacillus strains (18). To be able to apply standard phenotypical tests, they adapted the strains to neutral $\mathrm{pH}$ conditions and arranged them in five groups. They placed the strains loosely in the Bacillus firmus-Bacillus lentus complex (17). On the basis provided by these authors it was possible in 1985 to rearrange the strain groupings by applying genotypical tests and subsequent physiological tests under alkaline conditions (14). Groups in which phenotypical characteristics correlated with a distinct $\mathrm{G}+\mathrm{C}$ content were found. During these investigations a few strains were found to differ from all others. They revealed a combination of properties which had not been described before in the genus Bacillus: oval spores and no diaminopimelic acid (Dap) in the cell wall.

Cell walls with a cross-linkage between the peptide side chains other than via Dap had been found within the genus Bacillus until today only with the round-spore-forming species. This coincided with the more recent findings of Stackebrandt et al. (32) and Ash et al. (2) that these organisms (together with a number of related nonsporeformers) build a separate cluster when the $16 \mathrm{~S}$ rRNA nucleotide sequences are compared. Alexander and Priest (1) found with their numerical analysis distinctive round-spored taxa. In a previous comprehensive study on the numerical classification of the genus Bacillus (28) Priest et al. stated, "It is evident that the genus Bacillus now encompasses some 80 taxa of approximate species rank that can be assigned to five or more cluster groups. The latter should be used as a framework for redefining the current genus and splitting it into several genera." A possible separation of the round-spore-forming organisms from the genus Bacillus, which presently spans a

\footnotetext{
${ }^{*}$ Corresponding author.
}

moles percent $\mathrm{G}+\mathrm{C}$ range far too large as to be acceptable for a single genus, has therefore been discussed. Unfortunately, the convincing uniform picture had been disturbed by the finding that a round-spore-forming species, "Bacillus aminovorans," contains Dap in the cell wall (32) and the occurrence of round- and oval-spore-forming Bacillus sphaericus strains. However, $B$. sphaericus has now been separated into several DNA homology groups (1), and it is not yet clear whether the oval-spore-forming $B$. sphaericus strains can be found in a distinct group or whether they also lack Dap. The strains described in the present study add to this disturbance.

Further distinguishing properties of the Dap-less strains were as follows: the terminally positioned spore swells the sporangium, and growth occurs at around $\mathrm{pH} 9.7$ and up to $47^{\circ} \mathrm{C}$. Relatively high DNA homology values among these strains and low homology values with all other tested strains (14) supported the unique position of these organisms among the akaliphiles.

In this work additional strains with these properties were isolated and together with the strains of Fritze et al. (14) subjected to phenotypical and genotypical tests.

\section{MATERIALS AND METHODS}

Bacterial strains. The bacterial strains used in this study are listed in Table 1. Four strains were obtained from the National Collections of Industrial and Marine Bacteria Ltd., Torry Research Station, Aberdeen, Scotland. One strain was provided by $\mathbf{K}$. Aunstrup, Novo Industri, Copenhagen, Denmark, and one strain came from H.-G. Trüper, Bonn, Germany. Nine strains were isolated from samples collected in the area of Braunschweig from several places which were up to $10 \mathrm{~km}$ apart. Five strains received from the DSMDeutsche Sammlung von Mikroorganismen und Zellkulturen $\mathrm{GmbH}$, Braunschweig, Germany (DSM), were isolated from the Wadi Natrun, Egypt. The reference strains (type strains) used were obtained from the DSM. These strains are not listed in Table 1 (B. circulans DSM $11^{\mathrm{T}}, B$. alcalophilus DSM $485^{\mathrm{T}}, B$. lentus DSM $9^{\mathrm{T}}, B$. pantothenticus DSM $26^{\mathrm{T}}$, B. marinus DSM $1297^{\mathrm{T}}$, B. fusiformis, DSM $2898^{\mathrm{T}}, B$. insolitus DSM $5^{\mathrm{T}}$, and $B$. sphaericus DSM $28^{\mathrm{T}}$ ). 
TABLE 1. List of bacterial strains used in this study

\begin{tabular}{|c|c|c|c|c|}
\hline Name & $\begin{array}{c}\text { Source and/or collection } \\
\text { number }\end{array}$ & $\begin{array}{c}\text { Strain } \\
\text { designation }\end{array}$ & Reference(s) & Isolation source \\
\hline \multirow[t]{2}{*}{ B. circulans } & DSM 2528 & RU 38 & $8,15,19$ & $\begin{array}{l}\text { Contamination on an agar plate } \\
\text { with a high } \mathrm{pH} \text { value }\end{array}$ \\
\hline & NCIB 9218 & & & \\
\hline Bacillus sp. & NCIB 10284 & C 325 & $2 a, 15,19$ & Infection on an alkaline agar plate \\
\hline Bacillus sp. & NCIB 10318 & C 373 & $2 a, 15,19$ & Garden soil, city \\
\hline Bacillus sp. & NCIB 10327 & C 413 & $2 a, 15,19$ & Loam, grass field \\
\hline Bacillus sp. & K. Aunstrup & PB38(2) & $2 a, 15,19$ & \\
\hline Bacillus sp. & H. G. Trüper & M 5 & 15 & Mono Lake, California \\
\hline Bacillus sp. & DSM & $5 \mathrm{~A}$ & & Water + sand, Wadi Natrun, Egypt \\
\hline Bacillus sp. & DSM & $5^{\prime} \mathrm{A}$ & & Water + sand, Wadi Natrun, Egypt \\
\hline Bacillus sp. & DSM & $14 \mathrm{~B}$ & & Water + sand, Wadi Natrun, Egypt \\
\hline Bacillus sp. & DSM & $15 \mathrm{~B}$ & & Water + sand, Wadi Natrun, Egypt \\
\hline Bacillus sp. & DSM & $15^{\prime} \mathrm{B}$ & & Water + sand, Wadi Natrun, Egypt \\
\hline Bacillus sp. & Isolated for this work & RSA & & Old horse feces \\
\hline Bacillus sp. & Isolated for this work & RSB & & Old horse feces \\
\hline Bacillus sp. & Isolated for this work & RSF & & Soil, horse meadow \\
\hline Bacillus sp. & Isolated for this work & $\mathrm{RSH}^{\mathrm{T}}$ & & Soil, horse meadow \\
\hline Bacillus sp. & Isolated for this work & RSQ & & Old horse feces \\
\hline Bacillus sp. & Isolated for this work & RST & & Old horse feces \\
\hline Bacillus sp. & Isolated for this work & RSU & & Soil from field \\
\hline Bacillus sp. & Isolated for this work & RS2 & & Soil from field \\
\hline Bacillus sp. & Isolated for this work & RS6 & & Soil from field \\
\hline
\end{tabular}

${ }^{a}$ NCIB, National Collection of Industrial Bacteria (now National Collections of Industrial and Marine Bacteria [NCIMB]), Torry Research Station, Aberdeen, Scotland; DSM, DSM-Deutsche Sammlung von Mikroorganismen und Zellkulturen GmbH, Braunschweig, Germany.

Enrichment and isolation. Samples were taken from alkaline or possibly alkaline environments such as soil of horse meadows and fields or from old horse feces. Five steps of enrichment and selection were applied to isolate strains with the properties mentioned above. (i) For pasteurization, $1 \mathrm{~g}$ of sample material was mixed with $5 \mathrm{ml}$ of water, and $1 \mathrm{ml}$ of the supernatant was heated at $80^{\circ} \mathrm{C}$ for $10 \mathrm{~min}$. (ii) For incubation, after autoclaving, the $\mathrm{pH}$ value of a meat extractpeptone medium (nutrient broth; Difco) was adjusted to 9.7 by adding sodium sesquicarbonate solution to a final concentration of $0.1 \mathrm{~mol} / \mathrm{liter}$ (3). Tubes were inoculated with 1 to 2 drops of the pasteurized suspension and incubated aerobically at $45^{\circ} \mathrm{C}$ for 1 to 2 days. (iii) The cultures were streaked onto agar plates with a $\mathrm{pH}$ value of 9.7 (same medium as above plus agar) to obtain single colonies. The plates were incubated at $45^{\circ} \mathrm{C}$ or at 28 to $30^{\circ} \mathrm{C}$ for 2 to 7 days. Only a few morphologically different types of colonies developed on these plates. (iv) Upon microscopical examination of cells of the colonies, cells with the morphological properties described above were found only in the seldomoccurring, small, cream white colonies. These were selected, and a pure culture was made. (v) The test for the presence of Dap was thin-layer chromatography according to the method of Kutzner (23).

Chemotaxonomical characterization. These tests were performed by using previously described methods: cell wall analysis (29), analysis of the fatty acids $(24,26)$, and analysis of the polar lipids and quinones $(4,34)$.

Physiological characterization. Unless otherwise stated, the strains were characterized by using the modified methods of Gordon et al. (16). After autoclaving, the $\mathrm{pH}$ value of the media was adjusted to 9.7 by adding sodium sesquicarbonate solution to a final concentration of $0.1 \mathrm{~mol} / \mathrm{liter}(3)$. The media used for nitrate reduction and phenylalanine deamination tests had to be acidified prior to examining the activity of the strains. The following tests were performed by using previously described methods: $\mathrm{KOH}$ test (19), oxidase test (22), aminopeptidase activity test (test strips; Merck, Darmstadt, Germany) (6), Tween test (30), pullulanase test (27), and 4-methylumbelliferone glucuronidase (MUG) test (13). Splitting of urea was tested by inoculating the medium (per liter of $\mathrm{H}_{2} \mathrm{O}$ : urea, $20 \mathrm{~g}$; $\mathrm{KH}_{2} \mathrm{PO}_{4}, 9.1 \mathrm{~g}$; $\mathrm{Na}_{2} \mathrm{HPO}_{4}$. $12 \mathrm{H}_{2} \mathrm{O} 9.5 \mathrm{~g}$; yeast extract, $0.1 \mathrm{~g}$; phenol red, $0.01 \mathrm{~g}$; distributed in $1-\mathrm{ml}$ amounts into test tubes) with 2 to 3 drops of a heavy suspension of a culture grown overnight and washed twice with saline. For the test for obligate alkaliphily, the meat extract-peptone agar medium was buffered at pH 7 by adding the McIlvaine citrate-phosphate buffer. No growth at this $\mathrm{pH}$ value indicated that the particular strain is alkaliphilic, not only alkalitolerant.

Isolation of DNA. The DNA was isolated by using hydroxylapatite (hydroxylapatite for column chromatography, BioGel HTP; Bio-Rad, Richmond, Calif.) as described by Cashion et al. (5); DNA solutions obtained by this method were dialyzed shortly against $0.1 \times \mathrm{SSC}(1 \times \mathrm{SSC}: 0.15 \mathrm{M} \mathrm{NaCl}$ plus $0.015 \mathrm{M}$ sodium citrate) and were concentrated with 2-butanol by using the method of Stafford and Bieber (33).

G+C content. DNA solutions were dialyzed against 500 volumes of $1 \times \mathrm{SSC}$ at $4^{\circ} \mathrm{C}$ for 3 days with frequent change of buffer. The $\mathrm{G}+\mathrm{C}$ content was determined by using a Gilford model 2600 spectrophotometer equipped with a thermoprogrammer. Thermal denaturation $\left(T_{m}\right)$ values were calculated from computer-analyzed melting curves of preparations in $1 \times$ SSC by using the method of Marmur and Doty (25) with modifications from $\mathrm{HuB}(20)$. The DNA concentration of the samples was adjusted to an $A_{260}$ of 0.4 in $1 \times$ SSC. In each measurement, a DNA sample of Escherichia coli $\mathrm{K}-12$ wild type DSM $498(\mathrm{G}+\mathrm{C}=51.7 \%)$ was used as a reference and the moles percent $\mathrm{G}+\mathrm{C}$ content was calculated from $2.44 \times$ $\left(T_{m}-69.37\right)(10)$. Each experiment was carried out three times.

DNA-DNA hybridization. DNA-DNA homology values were determined spectrophotometrically from the renaturation rates of the individual DNA samples and their mixtures 


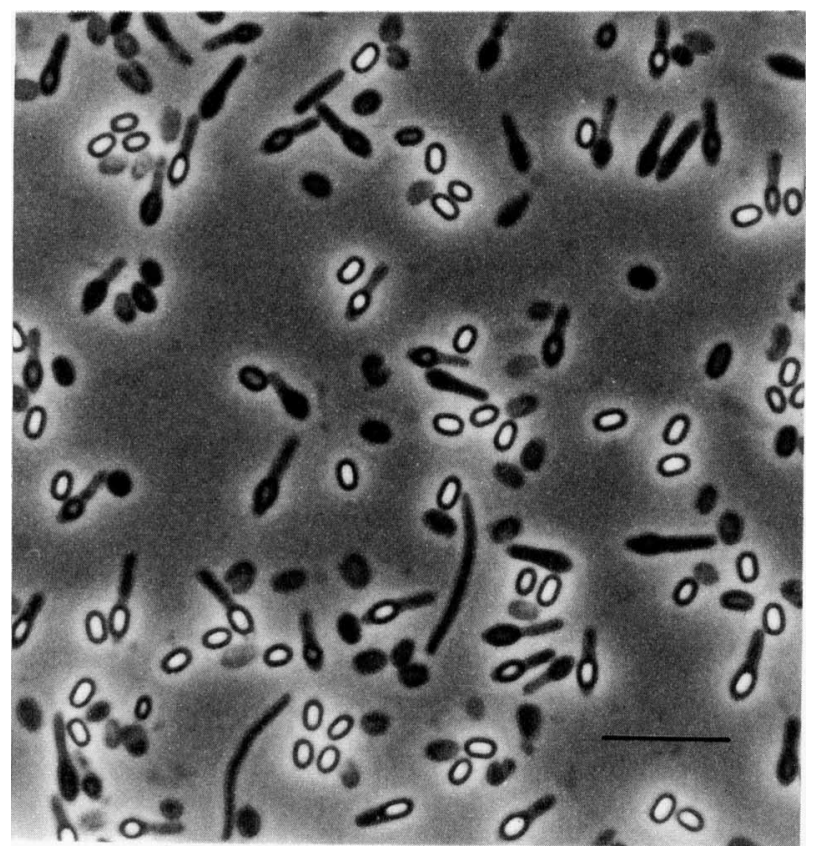

FIG. 1. Photomicrograph of the strain $\mathrm{RSH}^{\mathrm{T}}$. Bar $=10 \mu \mathrm{m}$.

by using the method of De Ley et al. (12) as described by Fritze et al. (14). Optimal renaturation temperature $\left(T_{\mathrm{OR}}\right)$ was calculated from the equation given by Gillis et al. (15). Recording of the decrease in $A_{260}$ for $30 \mathrm{~min}$ as well as calculation of the renaturation rates with linear regression was done by computer. The degree of binding $(D)$ was calculated from the equation given by De Ley et al. (12). Each experiment was carried out two to three times.

\section{RESULTS}

Twenty Bacillus strains with the properties of growth at $\mathrm{pH} 9.7$ and $47^{\circ} \mathrm{C}$, no Dap in the cell wall, and terminally located oval spores that distend the sporangium have been examined (Fig. 1). When analyzed, all 20 strains showed a cell wall structure classified as $\mathrm{A}_{4} \beta$-murein according to the nomenclature of Schleifer and Kandler (29). In the type of cell wall found here, Dap is replaced by ornithine and aspartic acid forms an interpeptide bridge (L-Orn-D-Asp) (Fig. 2).

The $\mathrm{G}+\mathrm{C}$ content of all 20 strains spans from $33.5 \mathrm{~mol} \%$

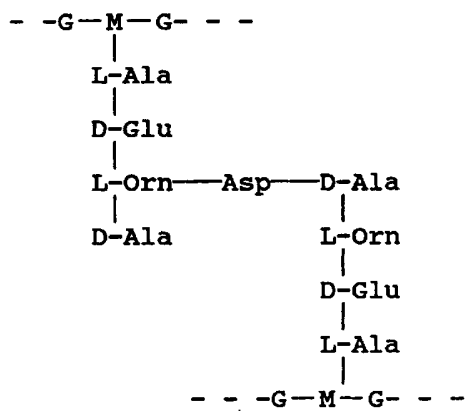

FIG. 2. Structure of the cell wall. G, $N$-acetylglucosamine; $\mathrm{M}$, $N$-acetylmuramic acid; L-Ala, L-alanine; Asp, aspartic acid; D-Glu, D-glutamic acid; L-Orn, L-ornithine.
TABLE 2. $\mathrm{G}+\mathrm{C}$ values in numerical order

\begin{tabular}{|c|c|}
\hline Strain(s) & $\begin{array}{c}\mathrm{Mol} \% \mathrm{G}+\mathrm{C} \\
\text { content }\end{array}$ \\
\hline 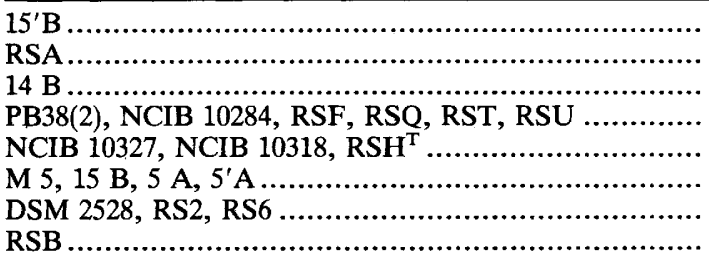 & $\begin{array}{l}33.5 \\
33.9 \\
34.1 \\
34.5 \\
34.6 \\
34.7 \\
34.8 \\
35.0\end{array}$ \\
\hline
\end{tabular}

(strain $15^{\prime} \mathrm{B}$ ) to $35.0 \mathrm{~mol} \%$ (strain RSB) (Table 2), suggesting that the strains might belong to one species. De Ley (11) recommends that the $\mathrm{G}+\mathrm{C}$ range of members of one species should not exceed the interval of $\pm 1 \mathrm{~mol} \%$. At the same time it cannot be assumed that strains with similar $\mathrm{G}+\mathrm{C}$ contents necessarily belong to one species.

A differentiation into taxonomically relevant groups was obtained from the results of the DNA-DNA hybridization experiments (Table 3 ). The $70 \%$ border recommended by Wayne et al. (36) as the lowest homology value for two strains belonging to the same species was employed. On the basis of these experiments it was possible to arrange the strains into six DNA homology groups (Table 3), of which each might represent an individual species. Between groups 1 to 5 homology values of 45 to $63 \% D$ were found. Strain 14B (homology group 6) showed only 23\% homology to strain NCIB 10318 (homology group 1).

Fatty acids with a chain length of 14 to 17 carbon atoms were detected. Only small amounts of $\mathrm{C}_{18}$ fatty acids were found. The $\mathrm{C}_{15: 0}$ iso and anteiso fatty acids predominate, with the $\mathrm{C}_{15 ; 0}$ anteiso fatty acids usually outweighing the $\mathrm{C}_{15: 0}$ iso fatty acids. Of all fatty acids determined, the iso and anteiso branched fatty acids amounted to the biggest proportion. The percentage of unsaturated fatty acids ranges from $19 \%$ (strain $5 \mathrm{~A}$ ) to $35 \%$ (strain 14B).

A pattern of polar lipids containing diphosphatidylglycerol, phosphatidylethanolamine, and phosphatidylglycerol was detected with all 20 strains.

Menaquinone 7 was determined to be the main lipoquinone fraction for all of the 20 strains $(95.8$ to $100 \%)$. Only strain RST contained significant amounts of menaquinone 3 (27.8\% menaquinone $3 ; 72.2 \%$ menaquinone 7 ).

All 20 strains showed a relatively uniform pattern of physiological and biochemical properties. The data for properties differing among the strains are listed in Table 4. Positive reactions for all strains were recorded for the oxidase and catalase tests, growth in the range from 25 to $45^{\circ} \mathrm{C}$, and hydrolysis of Tween 60 , hippurate, and gelatin. Negative reactions for all strains were recorded for lysis by $\mathrm{KOH}$, growth at 6 and $50^{\circ} \mathrm{C}$, deamination of phenylalanine, splitting of urea, and the presence of Dap in the cell wall.

\section{DISCUSSION}

One of the DNA homology groups $(D>70 \%)$ described in the study on alkaliphilic Bacillus strains of Fritze et al. (14) comprised three strains: PB38(2), NCIB 10284, and NCIB 10327. Three further strains, NCIB 10318, DSM 2528, and M 5 , showed 52 to $56 \%$ homology to this group. With each other these revealed $72 \%$ (NCIB 10318 and DSM 2528), 55\% (NCIB 10318 and M 5), and 57\% (M 5 and DSM 2528) homology. All of these six strains had the unusual combina- 
TABLE 3. DNA-DNA homologies

\begin{tabular}{|c|c|c|c|c|c|c|c|c|c|c|c|c|}
\hline \multirow{2}{*}{$\begin{array}{l}\text { Homology } \\
\text { group }\end{array}$} & \multirow{2}{*}{ Strain } & \multicolumn{11}{|c|}{$\%$ Homology $y^{a}$ with: } \\
\hline & & NCIB 10318 & DSM 2528 & $\mathrm{RSH}^{\mathrm{T}}$ & PB38(2) & NCIB 10284 & NCIB 10327 & $15 \mathrm{~B}$ & $15^{\prime} \mathrm{B}$ & $5 \mathrm{~A}$ & $5^{\prime} \mathrm{A}$ & M S \\
\hline \multirow[t]{10}{*}{1} & DSM 2528 & 77 & & & & & & & & & & \\
\hline & RSA & 79 & - & & & & & & & & & \\
\hline & RSB & 83 & - & & & & & & & & & \\
\hline & RSF & 79 & - & & & & & & & & & \\
\hline & $\mathrm{RSH}^{\mathrm{T}}$ & 85 & - & & & & & & & & & \\
\hline & RSQ & 80 & - & - & & & & & & & & \\
\hline & RST & 83 & - & - & & & & & & & & \\
\hline & RSU & 81 & - & - & & & & & & & & \\
\hline & RS2 & 81 & - & - & & & & & & & & \\
\hline & RS6 & 82 & - & - & & & & & & & & \\
\hline \multirow[t]{3}{*}{2} & PB38(2) & 54 & - & 53 & & & & & & & & \\
\hline & NCIB 10284 & 57 & - & - & 86 & & & & & & & \\
\hline & NCIB 10327 & 60 & (56) & - & $(85)$ & (96) & & & & & & \\
\hline \multirow[t]{2}{*}{3} & $15 \mathrm{~B}$ & 58 & - & - & - & - & - & & & & & \\
\hline & $15^{\prime} \mathrm{B}$ & 58 & - & - & 54 & - & 一 & 89 & & & & \\
\hline \multirow[t]{2}{*}{4} & $5 \mathrm{~A}$ & 62 & - & - & - & - & - & - & 63 & & & \\
\hline & $5^{\prime} \mathrm{A}$ & 59 & - & - & 50 & - & - & - & 57 & 89 & & \\
\hline 5 & M 5 & 60 & $(57)$ & - & - & - & $(52)$ & - & 45 & 60 & - & \\
\hline 6 & $14 \mathrm{~B}$ & 23 & - & - & ND & ND & ND & ND & ND & ND & ND & ND \\
\hline
\end{tabular}

${ }^{a}$ - , not determined since DNA-DNA homology values compared with those of selected representatives of a homology group indicate that they are in the same species $(>70 \%)$ or are not in the same species $(<70 \%)$. ND, not determined. Values in parentheses are taken from the study of Fritze et al. (14). Values were calculated as the means of two to three determinations.

tion of phenotypical properties in common: growth at $\mathrm{pH} 9.7$ and $47^{\circ} \mathrm{C}$, no Dap in the cell wall, and terminally positioned oval spores swelling the sporangium. More strains with this combination of properties were easily isolated with the described method.

Within the gram-positive bacteria the structure of the cell wall is of considerable taxonomic value. The vast majority of the hitherto described Bacillus species reveal a cell wall with the direct linked meso-Dap type. To date, only a few Bacillus species not containing Dap in their cell walls are described. All these species form round spores. The cell walls of all 20 strains examined in this study show a structure classified as $\mathrm{A}_{4} \beta$-murein type (L-Orn-D-Asp), which has not been described before in the genus Bacillus. A relatively similar type of cell wall can be found with the abovementioned round-spore-forming Bacillus species, e.g., $B$. insolitus, in which diaminopimelic acid is replaced by ornithine and the peptide chains are linked through glutamic acid (L-Orn-D-Glu); B. sphaericus, in which lysine is the diamino acid and aspartic acid is the interpeptide bridge (L-Lys-DAsp); and $B$. pasteurii, in which a combination of lysine and alanine take over the task of the diamino acid and aspartic acid again is the interpeptide bridge. A recent study revealed that with $B$. marinus the linkage is through L-lysine directly with a glycine bound to the carboxyl group (22a).

When regarding the composition of the cellular fatty acids of the organisms, the considerable amount of unsaturated fatty acids is striking. A similar proportion of unsaturated fatty acids had been found by Kaneda (21) for the group F organisms. Kaneda examined 19 Bacillus species for their fatty acid compositions and grouped them accordingly. Group F consisted of the round-spore-forming psychrophilic organisms $B$. insolitus and $B$. globisporus revealing 17 to $28 \%$ unsaturated fatty acids.
Close relationship to the mentioned species may also be seen through the relatively similar physiological behavior of the strains presented here with respect to their restricted range of carbohydrates from which acid may be produced (results not shown).

The pattern of polar lipids and quinones found with our strains seems to be typical for the genus Bacillus as it is presently described. Most of the Bacillus strains investigated until now possess phosphatidylglycerol and phosphatidylethanolamine. Collins and Jones reported that all Bacillus strains examined until now contain only menaquinones and as the main fraction usually menaquinone 7 (9).

All 20 strains examined in this study showed more or less similar behavior in most physiological and biochemical tests. On the basis of the DNA-DNA hybridization experiments with which six distinct homology groups could be found, it was possible to further interpret the physiological data. Although a much larger number of physiological properties needs to be determined for thorough characterization of these strains, a few of those might already be useful to distinguish between some of the homology groups presented here.

In Table 5 some differential characteristics of the six homology groups and of the type strains of Bacillus species in the same $\mathrm{G}+\mathrm{C}$ range are shown. Homology group 2 can be separated from homology group 1 through the inability of its strains to reduce nitrate to nitrite. The strains of homology group 3 grow, in contrast to strains of group 1, in the presence of $10 \% \mathrm{NaCl}$. Strain M 5 , the only strain of homology group 5, grows also, although weakly, in the presence of $10 \% \mathrm{NaCl}$. Strain $14 \mathrm{~B}$, the only member of group 6, differs from strains of group 1 in its inability to split MUG and by its narrower temperature range for growth. Only homology group 4 cannot be distinguished through the 


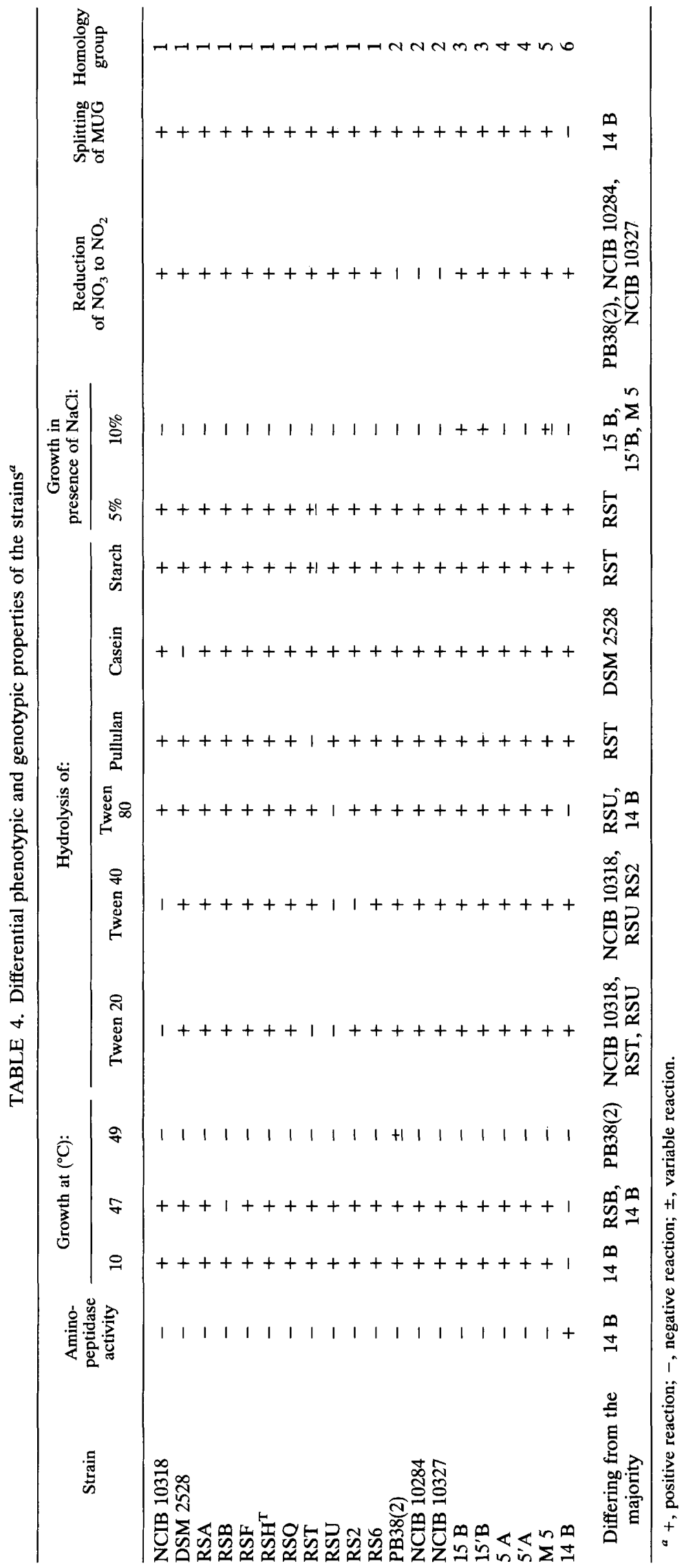


TABLE 5. Some differential characters of the six homology groups and of Bacillus species in the same $\mathrm{G}+\mathrm{C}$ range ${ }^{a}$

\begin{tabular}{|c|c|c|c|c|c|c|c|c|c|c|c|c|c|c|c|c|}
\hline \multirow[t]{2}{*}{ Group or strain } & \multicolumn{2}{|c|}{$\begin{array}{l}\text { Growth } \\
\text { at }\left({ }^{\circ} \mathrm{C}\right):\end{array}$} & \multicolumn{5}{|c|}{ Hydrolysis of: } & \multicolumn{2}{|c|}{$\begin{array}{l}\text { Growth in } \\
\text { presence } \\
\text { of } \mathrm{NaCl} \text { : }\end{array}$} & \multirow{2}{*}{$\begin{array}{l}\text { Nitrate } \\
\text { reduc- } \\
\text { tion }\end{array}$} & \multirow{2}{*}{$\begin{array}{l}\text { Splitting } \\
\text { of MUG }\end{array}$} & \multirow[t]{2}{*}{$\begin{array}{c}\mathrm{G}+\mathrm{C} \\
(\mathrm{mol} \%)\end{array}$} & \multirow[t]{2}{*}{ Dap } & \multirow[t]{2}{*}{$\begin{array}{l}\text { Alka- } \\
\text { liphile }\end{array}$} & \multirow{2}{*}{$\begin{array}{c}\text { Oval } \\
\text { spores }\end{array}$} & \multirow{2}{*}{$\begin{array}{c}\text { Swollen } \\
\text { sporangia }\end{array}$} \\
\hline & 10 & 47 & Hippurate & Gelatin & Pullulan & Casein & Starch & $5 \%$ & $10 \%$ & & & & & & & \\
\hline \multicolumn{17}{|l|}{ Homology groups } \\
\hline 1 & + & + & + & + & + & + & + & + & - & + & + & $33.9-35.0$ & - & + & + & + \\
\hline 2 & + & + & + & + & + & + & + & + & - & - & + & $34.5-34.6$ & - & + & + & + \\
\hline 3 & + & + & + & + & + & + & + & + & + & + & + & $33.5-34.7$ & - & + & + & + \\
\hline 4 & + & + & + & + & + & + & + & + & - & + & + & 34.7 & - & + & + & + \\
\hline 5 & + & + & + & + & + & + & + & + & \pm & + & + & 34.7 & - & + & + & + \\
\hline 6 & - & - & + & + & + & + & + & + & - & + & - & 34.1 & - & + & + & + \\
\hline \multicolumn{17}{|l|}{ Strains $^{b}$} \\
\hline B. sphaericus DSM $28^{\mathrm{T}}$ & - & - & - & + & - & + & - & - & - & - & - & 37.3 & - & - & - & + \\
\hline B. insolitus DSM $5^{\mathrm{T}}$ & + & - & + & - & ND & - & - & - & - & - & ND & 35.9 & - & - & - & - \\
\hline B. marinus DSM $1297^{\mathrm{T}}$ & + & - & - & + & - & - & - & + & - & - & - & 39.3 & - & - & - & + \\
\hline B. pantothenticus DSM $26^{\mathrm{T}}$ & - & - & - & - & - & - & + & - & - & + & - & 36.9 & + & - & \pm & + \\
\hline B. alcalophilus DSM $485^{\mathrm{T}}$ & + & - & - & + & + & + & + & - & - & - & - & 37.0 & + & + & + & - \\
\hline B. lentus DSM $9^{\mathrm{T}}$ & - & - & + & - & + & - & + & + & - & - & + & 36.3 & + & - & + & - \\
\hline B. circulans DSM $11^{\mathrm{T}}$ & - & + & - & + & + & - & \pm & + & - & - & + & 35.5 & + & - & + & + \\
\hline
\end{tabular}

$a+$, positive reaction; - , negative reaction; \pm , variable reaction; ND, not determined.

${ }^{b}$ Physiological-biochemical data for all strains except $B$. insolitus are from Fritze et al. (14). G+C values of all strains are from Fahmy et al. (12a).

presently chosen characters. The strains of groups 1 to 5 may be seen as members of closely related species, whereas the low homology value of strain 14 B (homology group 6) with group 1 and its different behavior in several phenotypical tests might indicate that this strain belongs to a more distantly related species.

The results shown suggest that the alkaliphilic oval-sporeforming strains with L-Orn-D-Asp instead of Dap in the cell wall represent a major group within the genus Bacillus that possibly contains several species occurring ubiquitously. Homology group 1 described in this work consists of 11 strains, which is a solid basis for a description of a species as recommended by Sneath (31).

Through DNA-DNA hybridization experiments with the type strains of other Bacillus species with similar $\mathrm{G}+\mathrm{C}$ contents it was shown previously (14) and in this study that there is no relationship within species level of these type strains to homology group 1 of this study. The following Bacillus species type strains were examined, and only low homology values were obtained: $B$. alcalophilus DSM $485(D$ $=25 \%), B$. circulans DSM $11(D=10 \%), B$. lentus DSM 9 $(D=8 \%), B$. pantothenticus DSM $26(D=16 \%), B$. marinus DSM $1297(D=38 \%)$, B. fusiformis DSM $2898(D=15 \%)$, $B$. insolitus DSM $5(D=19 \%)$, and $B$. sphaericus DSM $28(D$ $=17 \%$ ).

Strain DSM 2528 was isolated and described by Chislett and Kushner in 1961 (7) as B. circulans RU 38. In a later study (14) it was shown that the DNA-DNA homology value is only $17 \%$ between DSM 2528 (RU 38) and the type strain of $B$. circulans, DSM 11 . According to the present results, strain DSM 2528 belongs to a different species, which is described here.

On the basis of the given data the organisms of homology group 1 are considered strains of a new species, for which the name Bacillus cohnii is proposed. A description of this species is given below.

Description of $B$. cohnii sp. nov. Bacillus cohnii (coh'nii. M.L. gen. n. from Cohn; named after the German botanist and bacteriologist Ferdinand Cohn, who described the genus Bacillus in 1872).

Cells from overnight cultures are gram positive (no lysis by $\mathrm{KOH}$; no aminopeptidase activity). Cell width, 0.6 to 0.7 $\mu \mathrm{m}$; peritrichously flagellated. Spores oval and terminally located; sporangia swollen. Colonies are cream white on alkaline meat extract-peptone medium. After incubation at $45^{\circ} \mathrm{C}$ for 2 days the diameter of the colonies is 1 to $2 \mathrm{~mm}$. Catalase and oxidase positive. Obligately alkaliphilic. Minimum temperature of growth, $10^{\circ} \mathrm{C}$; maximum temperature of growth, $47^{\circ} \mathrm{C}$ (one strain negative). Growth at $5 \% \mathrm{NaCl}$; no growth at $10 \% \mathrm{NaCl}$. Nitrate is reduced. MUG is hydrolyzed. Hydrolysis of starch, pullulan (one strain negative), hippurate, Tween 20 (three strains negative), Tween 40 (three strains negative), Tween 60 , Tween 80 (one strain negative), gelatin, and casein (one strain negative) occurs. Urea is not hydrolyzed; phenylalanine is not deaminated. The cell wall is an $\mathrm{A}_{4} \beta$-murein with ornithine as the diamino acid and aspartic acid as the interpeptide bridge. The main proportion of the polar lipids consists of diphosphatidylglycerol, phosphatidylethanolamine, and phosphatidylglycerol. The main quinone is menaquinone 7 (96 to 100\%) (one strain exhibits significant amounts of menaquinone $3: 28 \%$ ). $\mathrm{C}_{15: 0}$ iso and anteiso fatty acids represent the main fraction of fatty acids ( 46 to $54 \%$ ). The proportion of unsaturated fatty acids amounts to 22 to $27 \%$. The $\mathrm{G}+\mathrm{C}$ content is 33.9 to 35.0 mol\%, as determined by the thermal denaturation method (strain $\mathrm{RSH}^{\mathrm{T}}, 34.6 \mathrm{~mol} \% \mathrm{G}+\mathrm{C}$ ).

Most of the strains were isolated from soil samples and feces collected in Denmark and in Germany. One strain was found as a contaminant on an agar plate in Great Britain. The type strain is strain RSH (= DSM 6307).

\section{REFERENCES}

1. Alexander, B., and F. G. Priest. 1990. Numerical classification and identification of Bacillus sphaericus including some strains pathogenic for mosquito larvae. J. Gen. Microbiol. 136:367-376.

2. Ash, C., J. A. E. Farrow, S. Wallbanks, and M. D. Collins. 1991. Phylogenetic heterogeneity of the genus Bacillus revealed by comparative analysis of small-subunit-ribosomal RNA sequences. Lett. Appl. Microbiol. 13:202-206.

2a.Aunstrup, K., et al. August 1971. British patent 1243784 .

3. Aunstrup, K., H. Outtrup, O. Andresen, and C. Dambmann. 1972. Proteases from alkalophilic Bacillus species, p. 299-305. In G. Terui (ed.), Proceedings of the Fourth International 
Symposium on Fermentation Technology. Society of Fermentation Technology, Osaka, Japan.

4. Bligh, E. G., and W. J. Dyer. 1959. A rapid method of total extraction and purification. Can. J. Biochem. 37:911-917.

5. Cashion, P., M. A. Holder-Franklin, J. McCully, and M. Franklin. 1977. A rapid method for the base ratio determination of bacterial DNA. Anal. Biochem. 81:461-466.

6. Cerny, C. 1978. Studies on the aminopeptidase test for the distinction of gram negative from gram positive bacteria. Eur. J. Appl. Microbiol. Biotechnol. 5:113-122.

7. Chislett, M. E., and D. J. Kushner. 1961. A strain of Bacillus circulans capable of growing under highly alkaline conditions. J. Gen. Microbiol. 24:187-190.

8. Cohn, F. 1872. Untersuchungen über Bacterien. Beitr. Biol. Pfianz. 1875 Band I (Heft 2):127-224.

9. Collins, M. D., and D. Jones. 1982. The distribution of isoprenoid quinone structural types in bacteria and their taxonomic implications. Microbiol. Rev. 45:316-354.

10. De Ley, J. 1970. Reexamination of the association between melting point, buoyant density, and chemical base composition of deoxyribonucleic acid. J. Bacteriol. 101:738-754.

11. De Ley, J. 1978. Modern molecular methods in bacterial taxonomy: evaluation, application, prospects, p. 347-357. In Proceedings of the Fourth International Conference on Plant $\mathrm{Pa}$ thology and Bacteriology.

12. De Ley, J., H. Cattoir, and R. Reynaerts. 1970. The quantitative measurement of DNA hybridisation from renaturation rates. Eur. J. Biochem. 12:133-142.

12a.Fahmy, F., J. Flossdorf, and D. Claus. 1985. The DNA base composition of the type strains of the genus Bacillus. Syst. Appl. Microbiol. 6:60-65.

13. Feng, P. C. S., and P. A. Hartmann. 1982. Fluorogenic assays for immediate confirmation of Escherichia coli. Appl. Environ. Microbiol. 43:1320-1329.

14. Fritze, D., J. Flossdorf, and D. Claus. 1990. Taxonomy of alkaliphilic Bacillus strains. Int. J. Syst. Bacteriol. 40:92-97.

15. Gillis, M., J. De Ley, and M. De Cleene. 1970. The determination of molecular weight of bacterial genome DNA from renaturation rates. Eur. J. Biochem. 12:143-153.

16. Gordon, R. E., W. C. Haynes, and C. H. Pang. 1973. The genus Bacillus. U.S. Dep. Agric. Agric. Handb. 427:3-14.

17. Gordon, R. E., J. C. Hyde, and J. A. Moore. 1977. Bacillus firmus-Bacillus lentus: a series or one species? Int. J. Syst. Bacteriol. 27:256-262.

18. Gordon, R. E., and J. L. Hyde. 1982. The Bacillus firmusBacillus lentus complex and pH 7.0 variants of some alkalophilic strains. J. Gen. Microbiol. 128:1109-1116.

19. Gregersen, T. 1978. Rapid method for distinction of gram negative from gram positive bacteria. Eur. J. Appl. Microbiol. Biotechnol. 5:123-127.

20. Huß, V. A. R. 1983. Untersuchungen zur spektrophotometrischen Bestimmung von Desoxyribonukleinsäure-Homologien am Beispiel der Gattungen Peptococcus und Peptostreptococcus. Dissertation. Technische Universität München, Munich.

21. Kaneda, T. 1977. Fatty acids of the genus Bacillus: an example of branched-chain preference. Bacteriol. Rev. 41:391-418.
22. Kovacs, N. 1956. Identification of Pseudomonas pyocyanea by oxidase reaction. Nature (London) 178:703.

22a.Kurth, G. Personal communication.

23. Kutzner, H. J. 1981. The family Streptomycetaceae, p. 20282090. In M. P. Starr, H. Stolp, H. G. Trüper, A. Balows, and H. G. Schlegel, The prokaryotes, vol. 2. Springer-Verlag KG, Berlin.

24. Kuykendall, L. D., M. A. Roy, J. J. O'Neill, and T. E. Devine. 1988. Fatty acids, antibiotic resistance, and deoxyribonucleic acid homology groups of Bradyrhizobium japonicum. Int. J. Syst. Bacteriol. 38:358-361.

25. Marmur, J., and P. Doty. 1962. Determination of the base composition of deoxyribonucleic acid from its thermal denaturation temperature. J. Mol. Biol. 5:109-118.

26. Miller, L. T. 1982. A single derivatization method for routine analysis of bacterial whole-cell fatty acid methyl esters, including hydroxy acids. J. Clin. Microbiol. 16:584-586.

27. Morgan, F. J., K. R. Adams, and F. G. Priest. 1979. A cultural method for the detection of pullulan-degrading enzymes in bacteria and its application to the genus Bacillus. J. Appl. Bacteriol. 46:291-294.

28. Priest, F. G., M. Goodfellow, and C. Todd. 1988. A numerical classification of the genus Bacillus. J. Gen. Microbiol. 134:18471882.

29. Schleifer, K. H., and O. Kandler. 1972. Peptidoglycan types of bacterial cell walls and their taxonomic implications. Bacteriol. Rev. 36:407-477.

30. Sierra, G. 1957. A simple method for the detection of lipolytic activity of microorganisms and some observations on the influence of the contact between cells and fatty substrates. Antonie van Leeuwenhoek J. Microbiol. Serol. 23:15-22.

31. Sneath, P. H. A. 1977. The maintenance of large numbers of strains of microorganisms, and the implication for culture collections. FEMS Microbiol. Lett. 1:333-334.

32. Stackebrandt, E., W. Ludwig, M. Weizenegger, S. Dorn, T. J. McGill, G. E. Fox, C. R. Woese, W. Schubert, and K.-H. Schleifer. 1987. Comparative 16S rRNA oligonucleotide analyses and murein types of round-spore-forming bacilli and nonspore-forming relatives. J. Gen. Microbiol. 133:2523-2529.

33. Stafford, D. W., and D. Bieber. 1975. Concentration of DNA solutions by extraction with 2-butanol. Biochim. Biophys. Acta 378:18-21.

34. Tindall, B. J., K. O. Stetter, and M. D. Collins. 1989. A novel fully saturated menaquinone from the thermophilic sulfatereducing archaeobacterium Archaeoglobus fulgidus. J. Gen. Microbiol. 135:693-696.

35. Vedder, A. 1934. Bacillus alcalophilus n. sp.; benevens enkele ervaringen met sterk alcalische voedingsbodems. Antonie van Leeuwenhoek J. Microbiol. Serol. 1:143-147.

36. Wayne, L. G., D. J. Brenner, R. R. Colwell, P. A. D. Grimont, O. Kandler, M. I. Krichevsky, L. H. Moore, W. E. C. Moore, R. G. E. Murray, E. Stackebrandt, M. P. Starr, and H. G. Trüper. 1987. Report of the Ad Hoc Committee on Reconciliation of Approaches to Bacterial Systematics. Int. J. Syst. Bacteriol. 37:463-464. 